\title{
Corruption and Legal Limits of Anti-Corruption Enforcement
}

Submitted 22/01/19, 1st revision 13/03/19, 2nd revision 20/04/19, accepted 05/06/19

\author{
Tsepelev V.F. ${ }^{1}$, Borisov A.V. ${ }^{2}$, Vlasov A.V. ${ }^{3}$, Drozdova E.A.. ${ }^{4}$ \\ Abstract:
}

Purpose: The article studies the issue of the limits to fight corruption in Russia within the framework of criminal law. The article is mainly devoted to the problems of combating corruption and its criminal law methods.

Design/Methodology/Approach: Authors analyzed the state of corruption taking into account public opinion and the general state of the law enforcement system. Authors also illustrated a criminological profile of an exactor.

Findings: The features of the specific crimes of the Criminal Code of the Russian Federation are studied in this article. Auhtors highlighted a number of points: first, the identity between the definitions of corruption as a negative social and legal phenomenon and second as crime itself.

Practical Implications: The article provides a detailed analysis and classification of corruption crimes under the Criminal Code of the Russian Federation, and proposes solutions to the identified problems aimed at improving the effectiveness of criminal law counteraction against bribery and other corruption phenomena.

Originality/Value: The main contribution of this study is a detailed analysis of the legal framework of the Russian Federation regarding the anti-corruption enforcement and contains solutions to improve the effectiveness of criminal law counteraction against bribery, other corruption crimes and corruption in general.

Keywords: Corruption, criminal policy, bribery, combating corruption.

JEL Code: K 14, K 22.

Paper Type: Research article in Special Issue dedicated to Russian Economy.

Section 5: Law, Constitutional, Social.

\footnotetext{
${ }^{1}$ Doctor of Law, Professor of the Department of Criminal Law of the Moscow State Law University, Professor, Department of Criminal Policy, Academy of Management, Ministry of Internal Affairs of Russia, Professor, Honored Lawyer of the Russian Federation, Moscow, Russian Federation, e-mail: v_tsepelev@rambler.ru

${ }^{2}$ PhD in Law, Head of the Department of Criminal Law, Criminal Procedure and Criminalistics of the Russian University of Transport, Moscow,e-mail: av-borisov@mail.ru

${ }^{3} \mathrm{PhD}$, Associate Professor of Customs Law and Organization of Customs, Law Institute of the Russian University of Transport, Moscow, e-mail: alessandro.vlasov@mail.ru

${ }^{4}$ Ph.D., Senior Researcher of the Department of Studying Domestic and Foreign Experience, History of the Penitentiary System, Comparative Analysis of the Penal Laws, Research Institute of the Federal Penitentiary Service of Russia, Associate Professor of Criminal Law, Criminal Procedure and Criminalistics, Russian University of Transport, Moscow, e-mail: gorbunovala@ya.ru
} 


\section{Introduction}

International and domestic experience in anti-corruption activity shows that the system for counteracting this negative social and legal phenomenon in general should include a complex of political, economic, social, ideological, legal and organizational measures implemented on a long-term basis. At the same time, legal measures should be considered and applied not as the main ones, but as maintaining, supporting of other measures.

As for legal measures, we should note that since corruption in Russia, like in other foreign countries, has become quite widespread, a complex of interrelated legal measures of civil, administrative, banking, currency, tax, customs, financial, immigration and other branches of legislation are needed. Then, the norms and institutions of criminal, criminal procedure and penal law will be established. All this determines an in-depth study of the problems of the legal regulation of countering corruption. This is a starting point for considering the problem of corruption from the standpoint of the relationship between public and private sector.

\section{The Urgency of the Problems of Combating Corruption in Russia}

As we know, corruption as a negative socio-legal phenomenon finds real expression in corruption offenses, the core of which is bribery. Despite all the existing and actually taken measures, corruption in general and bribery persist in many states of the world, regardless of the state and level of their political, economic and social development. However, it should be noted that the level and nature of corruption in different countries varies. In this regard, questions arisen are: what is the reason for such persistence? why has corruption and bribery become essentially the norm of social behavior?

It seems that the nature of the problem lies in a significant coincidence of private and public interest. Sociological studies indicate that almost half (more than 50\%) of the most active respondents aged between 25 and 45 are focused on working in the shadow sector of the economy and intend to tolerate the existence of corruption as an "inevitable" evil. The well-known Herzen (1969) said that "if the officials in Russia did not take bribes, it would be impossible to live in the country". According to the same survey, $40-45 \%$ of respondents support the fight against corruption and bribery (mainly, people over the age of 50, who have largely developed their labor resources and are not involved in entrepreneurial activities).

Assessing this situation, we can assume that private interest in this case, on the one hand, is in creating favorable conditions (through bribes) for the entrepreneurial activity of the person (both individuals and legal entities), on the other, in extracting a corrupt official - the recipient of mercenary or other benefit in exchange for wrongful behavior in the interests of the briber. Public interest here is manifested in the close relationship between the level of corruption and the index of economic 
freedom, which increases straight with corruption. However, it should be noted that this growth continues up to a certain limit (the so-called "turning point"). After reaching this point, the level of corruption tends to hinder the further economic development of the country and impede the improvement of the well-being of the population. Of course, in all cases the damage is done to the interests of the state and the society, the authority of state power, the interests of state and municipal service.

At present, the general population has a negative attitude towards corruption, according to a study by the Yuri Levada Analytical Center (2018), a Russian nongovernmental research organization, almost three-quarters of Russians (74\%) have a negative attitude towards solving using bribes. Every fourth person calmly perceives corruption (25\%). $89 \%$ of respondents consider corruption in the authorities unacceptable; only 5\% adhere disagree with this point of view. A third of respondents $(31 \%)$ believe that the bribee is more to blame. The fault of the briber is supported by $9 \%$. At the same time, $58 \%$ of respondents believe that both are equally to blame. According to $79 \%$ of Russians, corruption completely or largely struck the authorities (in 2016, 76\% thought so). 13\% believe that the authorities are affected by corruption to a small extent, and only $1 \%$ believed that there is practically no corruption in the state authorities. $43 \%$ of respondents say that the situation with the corruption in the country's authorities has not changed since the beginning of the 2000s. Improvements were only seen by $15 \%$ of respondents, $31 \%$ indicated an increase in the number of such facts, and $12 \%$ could not give an answer (Levada, 2018).

Moreover, the RF Procurator General generated a criminological profile of a typical corrupt official. So, mostly corrupt people are men between the ages of 39-49 years old, who have confidence in the future and are not afraid of punishment. At the same time, the proportion of women who committed a crime of corruption is almost two times higher than the proportion of women in all other crimes. People with higher education are among 80 percent of bribers. They have a family and children. A typical corrupt official, as a rule, does not abuse alcohol, does not take drugs, no complaints in the domestic context, he does not violate public order. The corrupt is motivated by self-interest and the strive to have a better life.

\section{Legal Anti-corruption Enforcement}

All this confirms the concern about the growth of corruption in the Russian Federation and the intolerance of the population to its manifestation.

Social practice revealed that the difficulties of the crisis period (slowdown of economic growth, deterioration of employment, inflation, etc.) promote the growth of corruption. Of course, it cannot be stated unequivocally that the degree of development of democracy reduces corruption. At the same time, it is necessary to take into account the opinion that a high level of crime in developed countries is an "inevitable price" for democracy. Does this mean that the combating corruption is 
impossible and unpromising? It seems no, because there are more significant interests and considerations, both public and private. They are associated with the highest needs of society, the state and individualities in establishing and maintaining a rule of law that would be based on the principles of legality, social justice, equality, economic freedom and expediency. Based on these values, a "tree of goals" and the whole complex of measures to fight corruption (political, economic, ideological, legal, organizational, logistical and others) should be introduced.

Such a conceptual approach is also reflected in legislation, primarily criminal and criminal procedure, which contains norms aimed at countering corruption crimes. So, according to art. 20 of Criminal Procedure Code, criminal cases of such crimes are classified as public prosecution cases. The ratio of private and public interest is expressed in the norms provided for by articles 201, 204-2042, 290-2912 and some others of the Criminal Code of the Russian Federation.

Considering the specifics of corruption offenses committed by officials, state and municipal employees, a number of important points previously noted in the legal literature should be highlighted (Malinovsky, 2004): first, a significant similarity between the definitions of corruption as a negative social and legal phenomenon and an official crime stipulated by art. 285 of the Criminal Code; second, the fact that the elements of crimes envisaged by Chapter 30 of Section X "Crimes against state power, interests of state service and service in local self-government bodies" of the Criminal Code of the Russian Federation contain criminally significant general features of corruption acts in general and entailing criminal liability, in particular.

In the current 1996 Criminal Code of the Russian Federation, Crimes, which with sufficient justification could be attributed to corruption, are located in various chapters of the Special Part. Using well-known classification criteria, they can be doctrinally divided into three main groups:

a) crimes offending the totality of public relations, ensuring the normal activity of state bodies and local governments, state and municipal institutions, state corporations, as well as military units and formations, which manifests itself in the interests of the service, enshrined in laws and by-laws (chapter 30 of the Criminal Code), namely: articles 285, 2851, 2852, 2853, 2854, 286, 287, 288, 289, 290, 291, 2911, 2912, 292, 2921 of the Criminal Code of the Russian Federation;

b) crimes offending the totality of public relations, ensuring the normal activity of business and other organizations that are not a state body, local government, state or municipal institution (Chapter 23 of the Criminal Code), namely Art. 201, 2011, 202, 204, 2041, 2042 of the Criminal Code;

c) crimes offending other objects of criminal law protection, but committed by officials, state or municipal employees, as well as persons performing managerial functions in commercial and other organizations using official powers, as well as intermediaries in the above actions, indicating that the above-mentioned public relations are the second party, namely: the "a" part 2 of art. 141, the relevant parts 
of art. 159, 1591, 1592, 1593, 1595, 1596, part 3 of Article 160, 169, 170, 1991, 1992, 1994, 304, part 1 of Article 309 of the Criminal Code of the Russian Federation.

\section{Conclusion}

We believe that anti-corruption measures of criminal law, in addition to those contained in the General and Special Parts of the Criminal Code of the Russian Federation, could include (by making appropriate amendments and amendments to the criminal law):

a) The possibility of applying to persons convicted for such crimes of extra punishment in the form of deprivation of the right to hold positions of state or municipal officials, as well as heads of public and commercial organizations, or engage in organizational or administrative activities for up to 20 years (as applied to persons convicted of sexual offenses against minors) or for life;

b) The possibility of applying to persons of general confiscation of property as an additional criminal penalty without the need to prove that it was obtained by criminal means (as a result of bribery).

These and other possible measures will allow, in our opinion, increasing the effectiveness of criminal law counteraction against bribery, other corruption crimes and corruption in general.

\section{References:}

CP Roadmap. 2017. Criminal Policy: the roadmap for 2017-2025. Center for Strategic Studies. Moscow, 73p.

Gazeta. 2018. Social and political Internet edition "Gazeta.ru". Available online: https://www.gazeta.ru/.

Herzen, A. 1969. Past and thoughts. Moscow, Fiction publishing, 924 p.

Levada. 2018. ANO Levada Center, Non-State Analytical Center. Available online: http://www.levada.ru/tag/korruptsiya/.

Malinovsky, I.B. 2004. Corruption: problems of criminal responsibility of state and municipal servants. Moscow, publishing house of Moscow University of the Ministry of Internal Affairs of Russia, $132 \mathrm{p}$. 